\title{
PENGARUH GOOD CORPORATE GOVERNANCE DAN UKURAN PERUSAHAAN TERHADAP PROFITABILITAS PADA PERBANKAN YANG TERDAFTAR DI BEI
}

\author{
Oleh: \\ Rolita Christina Purba \\ Universitas Sari Mutiara Medan \\ E-mail: \\ rolita.purba197ta@gmail.com
}

\begin{abstract}
The company seeks to struggle to survive by running their respective management functions so as to achieve goals and earn profits. This research was conducted with the aim of finding out the effect of good corporate governance and company size on profitability of banks listed on the IDX. The population in this study is the Banking that is listed on the Indonesia Stock Exchange (IDX) for the period 2017 to 2019 is 43 banks. The sampling technique in this study used a census, where all populations were sampled as a research multiplied by observation years to 129 observations.
\end{abstract}

Keywords: GCG, profitability, IDX and covid 19

\begin{abstract}
ABSTRAK
Perusahaan berupaya berjuang untuk bertahan hidup dengan cara menjalan fungsi manajemen masing-masing sehingga mencapai sasaran dan memperoleh laba. Penelitian ini dilakukan dengan tujuan untuk mengetahui pengaruh good corporate governance dan ukuran perusahaan terhadap profitabilitas pada Perbankan yang terdaftar di BEI. Populasi pada penelitian ini adalah Perbankan yang terdaftar pada Bursa Efek Indonesia (BEI) periode 2017 sampai dengan 2019 sebesar 43 Perbankan. Teknik pengambilan sampel pada penelitian ini dengan menggunakan sensus, dimana semua populasi dijadikan sampel peneltian dikalikan tahun pengamatan menjadi 129 observasi.
\end{abstract}

Kata kunci: GCG, profitabilitas, BEI dan covid 19.

PENDAHULUAN

Bank merupakan salah satu lembaga keuangan yang peranannya paling besar yang mengangkut pada bidang 
perekonomian. Perusahaan menggunakan bank sebagai tempat penyimpanan dananya dan selain itu juga sebagai tempat perkreditan dan jasa lainnya dalam menyalani pembiayaan dan pembayaran bagi semua sektor. Krisis ekonomi yang terjadi sekarang ini memberi dampak yang tidak baik bagi kinerja keuangan perusahaan. Seperti dampak COVID-19, penyebaran virus ini menjadi tantangan baru bagi pihak perusahaan dan perbankan di seluruh dunia. Pandemi ini juga telah mengganggu aktivitas ekonomi dibanyak Negara dan mendorong gerakan yang signifikan. (online, 25 April 2020). Implementasi GCG di Indonesia sampai saat ini masih belum memenuhi harapan, oleh karena itu, penerapan GCG diperlukan komitmen yang kuat dalam mewujudkan. (handani, 2016:111). Menghadapi implementasi di Indonesia merupakan kendala yang luar biasa dan saat ini GCG belum memberikan solusi tata kelola yang baik bagi perbankan. Lemahnya tata kelola perusahaan pada sektor perbankan menyebabkan tidak adanya checks and balance antara pelaksana kebijakan dengan formasi kebijakan. Terlihat dengan tidak adanya pengawasan terhadap pelanggaran batas minimum pemberian kredit (BMPK), maka terjadi kritis, pihak bank dihadapkan oleh permasalahan BMPK. Sadar akan hal tersebut, Bank Indonesia berupaya menata manajemen dan kegiatan perbankan lainnya dengan mengeluarkan Peraturan Bank Indonesia Nomor 8/4/PBI/2006 Tanggal 30 Januari 2006 tentang implementasi GCG oleh Bank Komersial yang diharapkan meningkatkan profitabilitas perusahaan. Kinerja keuangan merupakan gambaran hasil yang diperoleh oleh perusahaan. Alat ukur kinerja keuangan seperti rasio profitabilitas. Rasio profitabilitas berupa return on assets (ROA), rasio ini sering digunakan karena mudah dipahami dan rasio ini menggambarkan kinerja keuangan perusahaan termasuk perbankan. Perusahaan mampu meningkatkan laba atau profit perusahaan dan mempunyai peluang untuk melakukan ekspansi. Ekspansi ini sebagai tindakan aktif yang diperluas dan diperbesar oleh perusahaan. Perusahaan yang ukuran lebih besar akan berpengaruh terhadap peningkatan profitabilitas perusahaan. Peningkatan laba pada suatu perusahaan akan berdampak terhadap insentif yang diterima para karyawannya (Sinaga S (2020).

\section{KAJIAN PUSTAKKA \\ Rasio Profitabilitas}

Rasio profitabilitas merupakan salah satu rasio yang menganalisis laporan keuangan perusahaan. Rasio profitabilitas diproksikan dengan return on assets (ROA). ROA merupakan alat ukur kemampuan suatu perusahaan dimana aktivanya diperoleh untuk menghasilkan laba sehingga nilai ROA tinggi maka semakin bagus kinerja perusahaan. (Syamsuddin,2009:63).

\section{Good Corporate Governance (GCG)}

Banyak para ahli mengartikan tentang GCG namun pada intinya GCG merupakan suatu perangkat aturan yang diatur hak dan kewajibannya antar stakeholder pada 
perusahaan dan mewajibkan perusahaan untuk melakukan prinsip GCG seperti, transparansi, akuntabilitas, responbilitas, independen dan kesetaraan.

\section{a. Dewan direksi}

Berdasarkan peraturan Bank Indonesia nomor 11/33/PBI/2009, dewan direksi merupakan organ perseroan yang bertanggung jawab dan berwenang penuh atas pengurusan perseroan sesuai dengan maksud dan tujuannya serta mewakili baik dari dalam maupun dari luar sesuai dengan UU No 40 tahun 2007 tentang perseroan terbatas. Anggota dewan paling sedikit tiga orang dan kriteria untuk menjadi seorang direksi wajib memperhatikan rekomendasi dari komite remunerasi dan nominasi.

b. Dewan komisaris independent

Berdasarkan peraturan Bank Indonesia nomor 11/33/PBI/2009, komisaris independen meruapakan anggota dewan yang tidak mempunyai hubungan keuangan, pengurusan, hubungan keluarga atau pemilik saham dengan para pemegang saham dan dewan direksi. Jumlah komisaris independen paling sedikit lima puluh persen dari jumlah anggota dewan direksi dan tidak diperbolehan memiliki hubungan dengan pemilik saham dan bank sehingga dapat mendukung untuk bersikap independen. Tugas komisaris independen ini sebagai pembantu dewan direksi agar hasil tugasnya lebih efektif.

c. Dewan pengawas

Berdasarkan peraturan Bank Indonesia nomor 11/33/PBI/2009, dewan pengawas merupakan dewan yang tugasnya memberi saran dan nasehat kepada para direksi serta mengawasi kegiatan pihak bank yang sesuai dengan prinsip. Kriteria dan jumlah anggota dewan pengawas harus tunduk pada peraturan Bank Indonesia dan anggotanya berdasarkan RUPS.

d. Komite audit

Berdasarkan peraturan Bank Indonesia nomor 11/33/PBI/2009, komite audit dibentuk untuk membantu komisaris dan dewan pengawas dalam menentukan efektifitas pelaksanaan tugas auditor internal dan eksternal. Berdasarkan Badan Pengawas Pasar Modal (BAPEPAM) dengan surat edaran tahun 2003 berisikan bahwa tugas komite audit adalah sebagai pembantu dewan komisaris.

\section{Ukuran perusahaan}

Ukuran perusahaan menunjukkan jumlah total kekayaan perusahaan, semakin besar jumlah totalnya maka semakin besar juga ukuran perusahaan tersebut. Ukuran perusahaan merupakan jumlah dan variasi kapasitas produksi dan memiliki kemampuan dan pelayanan yang diberikan perusahaan secara bersamaan kepada pelanggan. (Velnampy, 2014:57). Baumann (2010) menjelaskan ada tiga teori hubungan ukuran perusahaan dengan profit perusahaan yaitu pertama, teori teknologi. Teori ini berfokus pada modal fisik dan ruang lingkup sebagai faktor penentu ukuran perusahaan yang dapat berpengaruh terhadap profitabilitas.

Kedua teori organisasi, dimana yang menghubungkan terori ini dengan 
profitabilitas yakni biaya transaksi organisasi, biaya agen dan kendali biaya. Dan terakhir biaya teori institusional, dimana teori yang dihubungkan dengan sistem hukum, peraturan hak paten, ukuran pasar dan pengembangan pasar keuangan.

\section{METODE PENELITIAN}

Berikut kerangka konsep pada penelitian ini sebagai berikut:

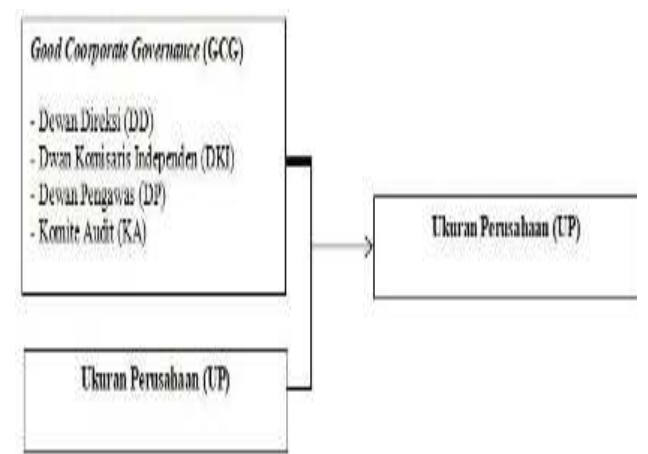

Gambar 1. Kerangka Konsep

\section{Hipotesis Penelitian}

Berikut hipotesis penelitian ini antara lain sebagai berikut :

1. Good coorporate governance (GCG) diproksikan dengan dewan direksi, dewan komisaris independen, dewan pengawas dan komite audit dan ukuran perusahaan secara simultan berpengaruh terhadap profitabilitas yang di proksikan dengan ROA pada perbankan yang terdaftar di BEI.

2. Good coorporate governance (GCG) diproksikan dengan dewan direksi, dewan komisaris independen, dewan pengawas dan komite audit dan ukuran perusahaan secara parsial berpengaruh terhadap profitabilitas yang di proksikan dengan ROA pada perbankan yang terdaftar di BEI.

Jenis penelitian yang dipakai adalah penelitian penjelasan (explanatory research) dengan pendekatan kuantitatif dimana pendekatan yang digunakan untuk menjelaskan dan mengetahui pengaruh good coorporate governance (GCG) dan ukuran perusahaan dengan profitabilitas. Good coorporate governance (GCG) diproksikan dengan dewan direksi, dewan komisaris independen, dewan pengawas dan komite audit, ukuran perusahaan dan profitabilitas yang di proksikan dengan ROA. Metode analisis data yang digunakan pada penelitian ini menggunakan dua metode yakni uji asumsi klasik dan analisis regresi linear berganda.

\section{POPULASI DAN SAMPEL}

Populasi pada penelitian ini adalah perusahaan perbankan yang terdaftar pada BEI dengan periode tiga tahun mulai dari 2017 sampai dengan 2019 berjumlah 43 perusahaan. Metode pengambilan sampel pada penelitian ini berupa sensus, dimana semua populasi dijadikan sampel pada penelitian ini sejumlah 43 dikalikan jumlah pengamatan sehingga sebesar 129 responden.

\section{HASIL DAN PEMBAHASAN Hasil Analisis Data}

Metode yang pertama untuk melakukan penelitian ini menggunakan uji asumsi klasik. Dimana pada uji ini menggunakan tiga tahap yaitu uji normalitas, uji heterokedastisitas dan uji multikolinearitas. Berikut hasil yang diperoleh pada uji normalitas.

Uji normalitas merupakan model regresi yang digunakan untuk menguji apakah nilai residual yang diperoleh dari regresi dikatakan 
normal atau tidak. Apabila nilai signifikansi $>0,05$ maka data berdistrubusi normal dan sebaliknya. Pada penelitian ini uji normalitas data menggunakan uji kolmogorovsmirirnov. Berikut hasil yang diperoleh pada uji normalitas.

Berdasarkan hasil penelitian dibawah, maka data dikatakan berdistrubusi normal karena nilai sig $(2$-tailed $)=0,171>0,05$.

Tabel 1. Uji Normalitas

One-Sample Kolmogorov-Smirnov Test

\begin{tabular}{|l|l|}
\hline & $\begin{array}{l}\text { Unstanda } \\
\text { rdiz ed } \\
\text { Residual }\end{array}$ \\
\hline $\mathrm{N}$ & 123 \\
Normal Parametersa & .0000000 \\
Std. Deviation & .8424096 \\
& 0 \\
Most Extreme Absolute & .100 \\
Differences Positive & .073 \\
Negative & -.100 \\
Kolmogorov-Smirnov Z & 1.108 \\
Asymp. Sig. (2-tailed) & .171 \\
\hline
\end{tabular}

a. Test distribution is Normal.

Uji multikolinearitas merupakan uji antarvariabel dimana model regresi ini memiliki hubungan linear yang mendekati kata sempurna. Cara mengetahui ada atau tidak gejala multikolinearitas dengan melihat nilai variance inflation factor (VIF) $<$ dari 10 dan tolerance $>0,1$ maka data tersebut dinyatakan tidak multikolinearitas. Berikut hasil penelitian dibawah ini.

Pada hasil penelitian ini, dapat dijelaskan bahwa data penelitian ini tidak terjadi multikolinearitas dikarenakan memenuhi kriteria.
Tabel 2. Uji Multikolinearitas

Coefficients ${ }^{a}$

\begin{tabular}{|ll|l|l|}
\hline \multirow{2}{*}{ Model } & \multicolumn{2}{|l|}{$\begin{array}{l}\text { Collinearity } \\
\text { Statistics }\end{array}$} \\
\cline { 3 - 4 } & & Tolerance & VIF \\
\hline 1 & DD & 827 & 1.209 \\
& DKI & .241 & 4.145 \\
DP & .255 & 3.925 \\
KA & .716 & 1.396 \\
UK & .971 & 1.030 \\
\hline
\end{tabular}

a. Dependent Variable: ROA

Uji heterokedastisitas merupakan jenis residual yang tidak sama pengamatan pada model ini. Regresi yang baik harus tidak terjadi heterokedastisitas. Metode pengujian ini menggunakan scatter plot dimana hasil nilai signifikan lebih besar dari 0,05 . Hasil pada peneltiian ini dapat dilihat pada tabel berikut.

Tabel 3. Uji Heterokedastisitas

\begin{tabular}{|c|c|}
\hline Model & Sig. \\
\hline $1 \quad$ (Constant) & .092 \\
\hline DD & .949 \\
\hline DKI & .044 \\
\hline DP & .000 \\
\hline KA & .662 \\
\hline
\end{tabular}




\section{\begin{tabular}{|l|l|} 
UK & .359 \\
\hline aDependent Variable: ROA
\end{tabular}}

Berdasarkan hasil uji heterokedastisitas diatas, maka dapat disimpulkan bahwa data penelitian ini tidak terjadi heterokedastositas.

\section{Pengujian Hipotesis Secara Simultan (Uji F)}

Pengujian ini digunakan untuk melihat hubungan atau oengaruh antar independen secara bersamasama terhadap variabel dependen dengan lebih kecil dari tingkat signifikan 0,05 dan jika nilai statistik hitung (F-Hitung) $>$ statistik tabel (FTabel) maka $\mathrm{H}_{0}$ ditolak dan sebaliknya. Berikut hasil pengujian pada tabel berikut.

Tabel 4. Uji F

\begin{tabular}{|ll|r|r|r}
\hline Model & & Sum of Squares & df & \\
\hline 1 & Regression & 17279.693 & 5 \\
& Residual & 83386.345 & 117 \\
& Total & 100666.038 & 122 \\
\hline
\end{tabular}

a. Predictors: (Constant), UK, DP, DD, KA, DKI

b. Dependent Variable: ROA

Hasil pada tabel diatas, menunjukkan nilai F-hitung sebesar $4,849>$ tabel sebesar 2,70. Dengan demikian $\mathrm{HO}$ ditolak dan $\mathrm{Ha}$ diterima. Artinya bahwa secar simultan terdapat pengaruh signifikan antara Good coorporate governance (GCG) diproksikan dengan dewan direksi, dewan komisaris independen, dewan pengawas dan komite audit, ukuran perusahaan dan profitabilitas yang di proksikan dengan ROA secara bersama sama.

\section{Pengujian Hipotesis Secara Parsial} (Uji t)

Pengujian secara parsial (uji t) digunakan untuk melihat gubungan antara variabel independen dan variabel dependen dengan nilai signifikan lebih kecil dari 0,05. jika H-hitung $>$ T-tabel, maka $\mathrm{H} 0$ ditolak dan sebaliknya. Berikut hasil pengujian uji-t pada tabel dibawah ini.

\section{Tabel 5. Uji-t \\ Coeficients}

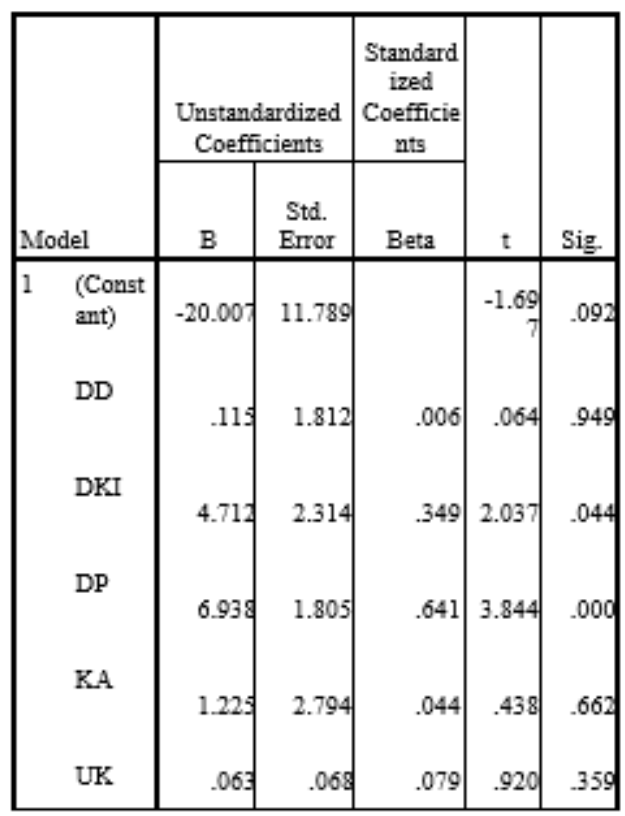

a. Dependent

Variable: ROA

Berdasarkan pada hasil pengujian uji $\mathrm{t}$ diatas, maka dapat dilihat persamaan penelitian ini adalah sebagai berikut:

ROA $=-20.007+$ 0,115DD + 4,712DKI + 6.938DP + 1,225KA + $0,063 \mathrm{UK}$

Berdasarkan hasil yang diperoleh pada tabel uji-t dilihat dari kolom sig diperoleh bahwa good corporate governance (GCG) 
diproksikan dengan dewan komisaris independen, dewan pengawas mempengaruhi secara signifikan terhadap profitabilitas yang diproksikan dengan ROA sedangkan pada good coorporate governance (GCG) diproksikan dengan dewan direksi dan komite audit, ukuran perusahaan tidak mempengaruhi secara signifikan tergadap profitabilitas yang diproksikan dengan ROA pada perbankan yang terdaftar di BEI dengan periode 2017 - 2019 .

\section{KESIMPULAN DAN SARAN}

Berdasarkan pada hasil analisis pada penelitian ini maka dapat disimpulkan antara lain sebagai berikut:

1. Secara simultan, good coorporate governance (GCG) diproksikan dengan dewan direksi, dewan komisaris independen, dewan pengawas dan komite audit, ukuran perusahaan dan profitabilitas yang di proksikan dengan ROA pada perbankan yang terdaftar di BEI dengan periode 2017 - 2019.

2. Secara parsial, good coorporate governance (GCG) diproksikan dengan dewan komisaris independen, dewan pengawas mempengaruhi secara signifikan terhadap profitabilitas yang diproksikan dengan ROA sedangkan ada good coorporate governance (GCG) diproksikan dengan dewan direksi dan komite audit, ukuran perusahaan tidak mempengaruhi secara signifikan tergadap profitabilitas yang diproksikan dengan ROA pada perbankan yang terdaftar di BEI dengan periode 2017 - 2019 .

\section{KETERBATASAN}

Berdasarkan hasil analisis penelitian ini, ditemukan beberapa batasan antara lain sebagai berikut:

1. Pada penelitian ini hanya menggunakan dua variabel idependen dalam mempengaruhi variabel dependen.

2. Populasi pada penelitian ini hanya meneliti satu sub sektor perusahaanyang terdaftar pada BEI

\section{SARAN}

Berdasarkan keterbatasan peneliti pada penelitian ini, maka saran yang diberikan untuk penelitian selanjutnya antara lain sebagai berikut:

1. Untuk peneliti selanjutnya, diharapkan menambah jumlah variabel independen dalam mempengaruhi variabel dependen.

2. Untuk peneliti selanjutnya, diharapkan menambah atau mengubah populasi penelitian, sehingga menambah wawasan lebih luas dalam pengaruh profitabilitas.

\section{DAFTAR PUSTAKA}

Bank Indonesia. Peraturan Bank Indonesia Nomor 8/4/PBI/2006 Tentang Pelaksanaan Good Corporate Governance Bagi Bank Umum. 2006.

Baumann, H. \& Blease, J. R. B., Kaen, F. R., Etebari, A. (2010). Employees, firm size and profitability in U.S. manufacturing industry. Investment Management amd Financial Innovations, 7(2), 6- 
13.

Ghozali, Imam.2009. Aplikasi Analisis Multivariance Dengan Program SPSS. Badan Penerbit Universitas Diponegoro.

Republik Indonesia. 1995. Undang-Undang No.8 Tahun 1995 Tentang Pasar Modal. Jakarta.

Syamsuddin, Lukman. 2009. Manajemen

KeuanganPerusahaan. Jakarta: PT. Raja Grafindo Persada.

Velnampy, T. \& Niresh, J. A., (2014). Firm size and profitability: a study of listed manufacturing firms in Sri Lanka. International Journal of Business and Management, 9(4), 57-64.

\section{Semarang}

Hamdani. 2016. Good Corporate Governance. Jakarta: Mitra Wacana Media.

Sinaga, S. (2020). PERANAN BALAS JASA DAN INSENTIF TERHADAP MOTIVASI KERJA PADA PT. SONY GEMERLANG MEDAN. Jurnal Darma Agung, 28(1), 132-144. doi:10.46930/ojsuda.v28i1.605 